\title{
KEEFEKTIFAN E-LEARNING DALAM PEMBELAJARAN MAHASISWA PADA MASA PANDEMI
}

Muhammad Zulfan Faizal, Wahyu Andhyka Kusuma

Universitas Muhammadiyah Malang (UMM) Jawa Timur, Indonesia

Email: zulfanfaizal@gmail.com,wahyukusuma@umm.ac.id

\begin{tabular}{|c|c|}
\hline & BSTRAK \\
\hline Diterima & \multirow{15}{*}{$\begin{array}{l}\text { Penelitian ini adalah merupakan penelitian deskriptif kualitatif } \\
\text { yang mengkaji tentang keefektifan e-learning pada } \\
\text { pembelajaran mahasiswa pada masa pandemi. Pembelajaran } \\
\text { jarak jauh ini akibat terdampak pandemi covid-19 yang } \\
\text { mengharuskan mahasiswa tidak memperoleh pembelajaran } \\
\text { tatap muka. e-learning Merupakan sistem pembelajaran jarak } \\
\text { jauh yang mengharuskan para mahasiswanya tetap melakukan } \\
\text { pembelajaran meskipun tidak bisa melakukan pembelajaran } \\
\text { tatap muka. Keefektifan juga perlu dalam sebuah pembangunan } \\
\text { sistem pembelajaran karena dalam sistem pembelajaran } \\
\text { keefektifan itu sangat berperan penting untuk berjalannya } \\
\text { sistem tersebut, Jika tanpa adanya keefektifan dalam suatu } \\
\text { pembelajaran maka akan sulit bagi pengajar maupun yang } \\
\text { mahasiswa. Pandemi merupakan wabah penyakit yang terjadi } \\
\text { pada seluruh dunia, dengan adanya pandemi ini bidang } \\
\text { pendidikan mengalami kesulitan untuk melakukan } \\
\text { pembelajaran tatap muka, maka cara pemerintah untuk } \\
\text { menanggulangi efek menyebar dari pandemi ini diterapkannya } \\
\text { sistem pembelajaran online atau yang bisa disebut e-learning. }\end{array}$} \\
\hline & \\
\hline & \\
\hline & \\
\hline & \\
\hline & \\
\hline Kata Kunci: & \\
\hline & \\
\hline & \\
\hline & \\
\hline & \\
\hline & \\
\hline & \\
\hline & \\
\hline & \\
\hline
\end{tabular}

\section{ABSTRACT}

This research is a qualitative descriptive study that examines the effectiveness of e-learning in student learning during the pandemic. Distance learning is a result of the covid-19 pandemic which requires students not to study face-to-face. $e$ learning is a distance learning system that is needed by students to keep learning even though you can't do face-to-face learning. Effectiveness is also necessary in a learning development system because in a learning system effectiveness is very important to run the system. If there is no effectiveness in learning, it will be difficult for both teachers and students. A pandemic is a disease outbreaks that occur throughout the world, with the pandemic in the field of education having Keywords: $\quad e$ - difficulty conducting face-to-face learning. The government's learning; way to cope with the spreading effects of this pandemic is to

$\begin{array}{ll}\text { How to cite: } & \text { Faizal, M. Z., \& Kusuma, W. A. (2021) Keefektifan E-Learning dalam } \\ & \text { Pembelajaran Mahasiswa pada Masa Pandemi. Jurnal Syntax Admiration 2(8). } \\ & \text { https://doi.org/10.46799/jsa.v2i8.286 } \\ \text { E-ISSN: } & \text { 2722-5356 } \\ \text { Published by: } & \text { Ridwan Institute }\end{array}$




\begin{tabular}{ll}
\hline effectiveness; & implement an online learning system which can be accessed \\
pandemic & through the internet. called e-learning.
\end{tabular}

\section{Pendahuluan}

Pada tahun 2020 pertengahan bulan maret di Indonesia mengalami situasi yang sangat mencekam yang diakibatkan oleh pandemi yang menyebar luas di seluruh wilayah Indonesia (Hariani \& Wastuti, 2020). Untuk itu Lembaga Pendidikan formal adalah suatu aspek yang harus diperhatikan untuk penanggulangan pada situasi wabah yang sedang menyerang ini. Lembaga Pendidikan juga diharuskan mampu untuk mencegah penyebaran virus covid-19 yang sangat cepat ini dengan memutuskan rantai penyebaran covid-19 itu sendiri,dengan cara menggunakan teknologi modern yang mengharuskan lembaga pendidikan formal tetap menjalankan pembelajaran dengan sistem pembelajaran jarak jauh berbasis online dengan maksimal. pada jurnal (Meliyani et al., 2019) menjelaskan kegiatan pembelajaran harus memiliki satu komponen yang perlu diperhatikan agar proses suatu pembelajaran dapat berkesinambungan dan memberikan pengaruh dalam pelaksanaannya. Seperti yang dijelaskan (Wibowo, 2020) bahwa di masa pandemi ini juga merupakan tantangan bagi para pendidik dikarenakan proses pemilihan media pembelajaran yang cocok seperti sistem pembelajaran $e$ learning ini sangat cocok jika digunakan pada masa pandemi seperti ini karena hanya membutuhkan sebuah komputer dan jaringan internet saja sudah bisa melakukan pembelajaran dengan lancar, Tetapi di (Engko \& Usmany, 2020) menjelaskan bahwa juga dosen merasa proses pembelajaran e-learning masih kurang maksimal karena dosen sendiri tidak tau bahwa materi yang dijelaskan sudah paham atau tidak dikarenakan tidak tatap muka.

Karakteristik e-learning yang dijelaskan (Wibowo, 2020) mengenai kemudahan bagi pendiik dan peserta didik sebagai pengakses dan pengelola pembelajaran serta bisa mengakses dan melakukan pembelajaran interaktif kapanpun dan dimanapun. Banyak juga macam-macam dari media e-learning seperti berikut: Google Classrom, Moodle, Edmodo dan masih banyak lagi dan pada media pembelajaran tersebut sudah memiliki fitur yang lengkap dari Forum diskusi hingga sistem penilaian yang otomatis.

Berbagai layanan e-Learning telah tersedia baik yang dikelola mandiri oleh institusi ataupun universitas menggunakan Learning Management System (LMS) maupun yang tersedia secara bebas seperti Google Classroom, Edmodo, dll yang disediakan bebas oleh pihak ketiga (Abi Yodha et al., 2019). Universitas Muhammadiyah Malang telah memiliki sistem pembelajaran e-learning yang sudah dikembangkan dengan menggunakan LMS Moodle dan telah digunakan sebagai salah satu bentuk pembelajaran yang telah setujui oleh pimpinan Universitas Muhammadiyah Malang. Dan tak jarang pengajar di kalangan Fakultas Teknik telah menggunakan ELearning ataupun aplikasi e-learning pihak ketiga.

Sistem e-learning juga sistem mutlak yang perlu dipakai saat pandemi dan menurut (Yuliana, 2020) sistem e-learning ini sangat diperlukan untuk mengantisipasi perkembangan zaman di era globlasisasi digital baik mekanisme maupun konten yang 
digunakan didalamnya. Tetapi menurut (Agus Susilo, 2013) masih banyak kekurangan di bagian sarana dan prasana yang perlu diperbaiki untuk mendukung efektifitas pembelajaran e-learning tersebut dan juga adanya faktor ekonomi adalah suatu hambatan bagi pembelajaran e-learning.

Meskipun banyak dampak tetapi pada (Puspitorini, 2020) menjelaskan bahwa dengan adanya kebijakan pemerintah untuk belajar secara online atau menggunakan $e$ learning dapat memberikan manfaat yaitu meningkatkan kesadaran akan teknologi yang semakin berkembang pesat.

Penelitian ini bertujuan untuk meningkatkan motivasi dan hasil belajar mahasiswa dengan penerapan model pembelajaran e-learning berbasis google classroom pada masa pandemi Covid-19, dan platform yang mendukung seperti google form untuk pengumpulan data motivasi belajar mahasiswa dan aplikasi zoom.us digunakan saat dosen menjelaskan materi pada mata kuliah Dasar Akuntansi dengan materi pokok jurnal penyesuaian, alasan mengunakan aplikasi zoom.us adalah dapat diakses secara gratis, jumlah partisipan mencapai 100 orang, kualitas suara dan gambar baik, hanya saja durasi dibatasi 40 menit (Daniati et al., 2020).

\section{Metode Penelitian}

Penelitian ini menggunakan pendekatan kualitatif,penelitian kualitatif merupakan metode yang lebih menekankan dalam aspek pemahaman secara mendalam terhadap suatu kasus daripada melihat konflik untuk penelitian generalisasi. Pendekatan yang digunakan dalam penelitian ini merupakan berupa pemaparan secara naratif mengenai tanggapan dan respon responden sebagai subjek penelitian mengenai Keefektifan $e$ learning dalam pembelajaran mahasiswa pada masa pandemi.

\section{Hasil dan Pembahasan}

\section{A. Hasil Penelitian}

Hasil penelitian yang diperoleh, menyatakan bahwa penerapan e-learning pada masa pandemi covid-19 sangat tepat. Mahasiswa dan dosen masih bisa melakukan pembelajaran, walaupun dilakukan secara jarak jauh atau tidak bertatap muka langsung di kelas. Ini dibuktikan dengan hasil 61,5\% mahasiswa yang merasa setuju menggunakan e-learning pada saat pandemi Covid-19. Hasil penelitian ini sesuai dengan hasil penelitian lain yang memberikan hasil, antara lain mahasiswa merasa tertarik dengan penerapan $e$-learning; penerapan e-learning memudahkan mahasiswa dalam mengikuti perkuliahan; penerapan e-learning dapat mencegah penularan covid-19 di kampus Selain itu ditemukan juga beberapa kendala yang terjadi pada mahasiswa, terutama mahasiswa dari orang tua dengan keadaan ekonomi kurang mampu, yang mana belum mampu untuk membeli komputer/laptop serta pulsa data. Karena perkuliahan semester sebelumnya dilakukan di kampus dengan fasilitas tersedianya komputer untuk latihan. Hasil penelitian ini juga sama dengan hasil survey dari peneliti lain yang menyatakan bahwa 50\% mahasiswa yang belum mempunyai laptop, sebanyak $80 \%$ mahasiswa menyatakan susah mendapatkan sinyal 
dan boros penggunaan paket data ini disebabkan karena banyak mahasiswa yang tinggal jauh dari daerah perkotaan (Sara et al., 2020).

\section{Kerangka Kerja Penelitian}

\section{Subjek Penelitian}

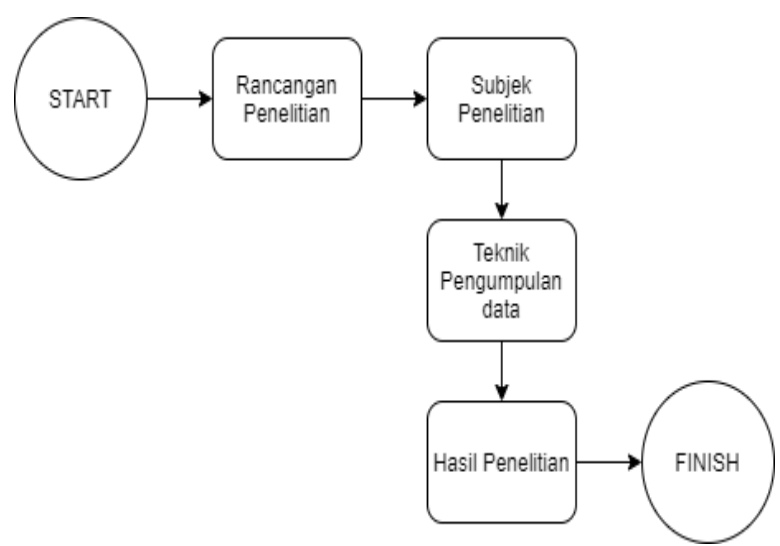

Gambar 1

Rancangan Penelitian

Subjek dalam penelitian ini yaitu mahasiswa Teknik informatika angkatan 2018 dan Perwakilan Dosen Informatika. Beberapa mahasiswa kelas 7H dan Perwakilan Dosen Informatika yang akan menjadi subjek dalam penelitian ini untuk mengetahui tingkat keefektifan e-learning dalam proses pembelajaran online ini terhadap dirinya masing-masing. Pengumpulan data dilakukan dengan menggunakan.

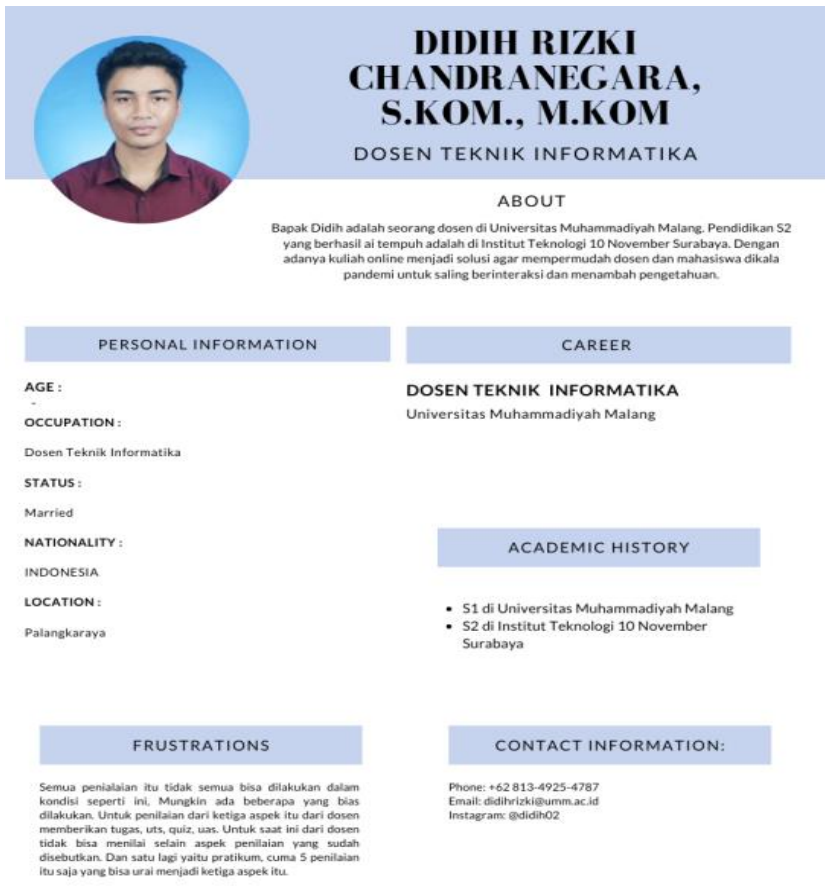

Gambar 2

User Persona Perwakilan Dosen 


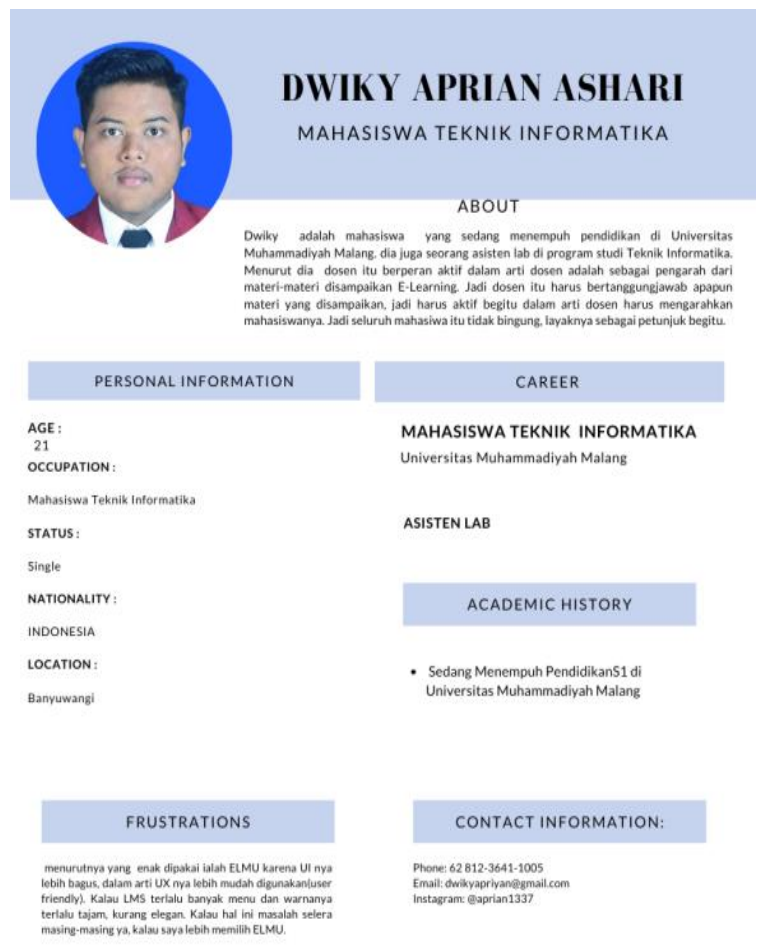

Gambar 3

User Persona Perwakilan Mahasiswa

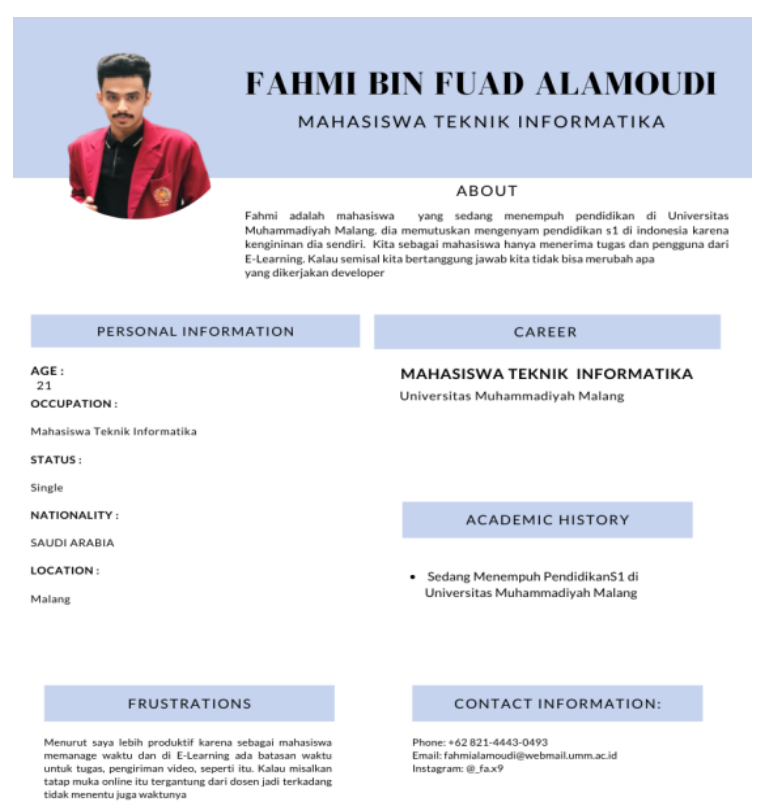

Gambar 4

User Persona Perwakilan Mahasiswa 


\section{Teknik Pengumpulan Data}

Data yang terdapat dalam penelitian ini adalah data deskriptif yang diperoleh dari survey angket dan wawancara dari beberapa mahasiswa kelas $7 \mathrm{H}$ dan perwakilan dosen informatika untuk wawancara mengenai keefektifan e-learning dalam Pembelajaran pada mahasiswa pada masa pandemi.

\section{Hasil Penelitian}

Menurut (Anggraini, 2018) Dari hasil penelitian menunjukkan bahwa $e$ learning mempermudah interaksi antara mahasiswa dengan bahan atau materi pelajaran untuk Pembuatan angket menggunakan media google formulir dan melakukan wawancara terhadap beberapa mahasiswa dan dosen. Penyebaran link angket kepada mahasiswa dilakukan melalui grup whatsapp angkatan. Wawancara dilakukan via google meet ke mahasiswa dan Dosen Perwakilan, satu persatu. Tujuan penyebaran dari angket dan wawancara tersebut untuk memperoleh tanggapan dari mahasiswa setelah mereka mengikuti perkuliahan menggunakan media pembelajaran online atau yang disebut e-learning dan tanggapan dosen soal mengasih pembelajaran terhadap mahasiswanya menggunakan $e$-learning.

\section{B. Pembahasan}

Hasil penelitian ini tidak jauh berbeda dengan penelitian (Sara et al., 2020) yang menunjukkan penggunaan e-learning sangat tepat di masa pandemi covid-19 ini. Mahasiswa dan dosen masih tetap bisa melakukan proses belajar mengajar meskipun dilakukan dari jarak jauh. 65\% mahasiswa percaya bahwa mereka setuju sepakat untuk menggunakan proses belajar mengajar dengan menggunakan $e$ learning selama pandemi covid-19, hasilnya membuktikan hal tersebut. Hasil dari penelitian ini konsisten dengan penelitian lain, termasuk hasil bagi mahasiswa yang menganggapnya menarik. Selain itu juga mahasiswa kerap mendapati kendala yang sedemikian seperti : kendala keuangan yang kurang begitu baik, orang tua yang belum mampu membelikan perangkat seperti laptop/komputer yang memadai untuk pembelajaran e-learning dan pulsa/data yang digunakan untuk kegiatan berlajar menggunakan e-learning, sulitnya mahasiswa yang berada di daerah terpencil untuk mendapat sinyal yang baik yang menjadikan data internet yang didapat dari pemerintah kurang begitu maksimal dan mungkin.

\section{Dampak Terhadap Mahasiswa}

Dampak terhadap mahasiswa pasti ada yaitu mahasiswa diharuskan belajar mandiri yang susahnya ketika materi yang menurut mahasiwa itu sendiri itu sulit untuk dipahami dan keterbatasan waktu untuk bertanya kepada dosen. Dan juga akses informasi apapun yang terkendala oleh sinyal dikarenakan seorang mahasiswa berada pada daaerah terpencil yang kurang begitu ada sinyal memadai untuk mengikuti kegiatan belajar online, Hal tersebut menyebabkan mahasiswa sedikit mengalami keterlambatan mengenai informasi dan terkadang mahasiswa dapat tertinggal informasi yang disampaikan oleh dosen yang berakibat mereka terlambat untuk mengumpulkan suatu tugas yang diberikan oleh dosen. 
Keterbatasan sarana dan prasana juga termasuk dampak terhadap mahasiswa juga seperti pada penjelasan (Banamtuan, 2021) yang jadi penghambat untuk kelancaran terhadap e-learning seperti yang belum mempunyai laptop dan handphone ataupun sudah memiliki laptop dan handphone tetapi device yang belum memadai untuk menjalankan e-learning sacara lancar.

Pada mata kuliah tertentu yang memerlukan praktikum secara tatap muka akan mengalami kurangnya pemahaman pada praktikum langsung, mungkin mahasiswa akan sedikit memahami teori yang sudah diajarkan tapi untuk praktikum secara langsung mahasiswa akan mengalami kesulitan jika dengan media e-learning dan mendapatkan ilmu yang kurang maksimal seperti pada (Wijaya et al., 2020) mahasiswa kurang paham tentang praktek secara langsung.

\section{Dampak Terhadap Dosen}

Pastinya pengaruh dosen sangat penting terhadap pembelajaran meskipun peran dosen tidak bisa digantikan seutuhnya oleh pembelajaran e-learning tetapi dengan adanya e-learning ini dapat membantu proses belajar mengajar pada waktu pandemi covid-19. Adapun dampak dari e-learning terhadap dosen seperti yang sudah dijalaskan di (Daniati et al., 2020) dan matakuliah yang berifat praktek yang biasa dilakukan dilab dengan adanya e-learning ini menjadi kurang efektif karena mahasiswa hanya diberi tugas tanpa ada arahan dan bimbingan langsung dari dosen matakuliah praktek tersebut seperti yang dijelaskan di penelitian (Astini, 2020).

Dampak terhadap dosen berikutnya masih banyak dosen masih awam dengan adanya e-learning meskipun e-learning sendiri sudah ada dari 2017 tetapi banyak dosen masih kebingungan dengan e-learning pada awalnya, Dan dosen merasakan kejenuhan mengajar online/daring lantaran dengan kebiasaan dosen dengan pembelajaran tatap muka yang lebih bisa interaksi dengan mahasiswanya.

\section{Pengembangan}

Pengembangan konten e-learning pada mata kuliah untuk penelitian ini adalah sebagai berikut:

1. Dijelaskan (Astuti \& Febrian, 2019) pengembangan bahan ajar online yang bisa diarsip dan diunduh oleh mahasiswa dan materi pelajaran sinkron dengan apa yang dosen sudah share berupa ppt dan pdf.

2. Pembelajaran Video

Dengan pembelajaran video yang diupload dosen lewat youtube milik dosen ataupun kelas online seperti google classroom, edmodo, lms dapat membantu mahasiswa bisa membuka kapanpun dan dimanapun untuk belajar lewat video yang praktis.

3. Tugas Online

Dengan adanya tugas online ini diharapkan mahasiswa dapat tertib untuk mengerjakan tugas dan diberi tenggat waktu yang sesuai keinginan dosen.

4. Forum Diskusi 
Sering mahasiswa dapat waktu diskusi yang singkat mengakibatkan mahasiswa menjadi bingung dengan materi dan menjafi ketinggalan maka dengan adanya forum diskusi perkelas ini menjadi solusi bagi mahasiswa yang masih belum mengerti materi tanpa adanya batas waktu untuk berdiskusi.

\section{Kuis Online}

Dengan adanya kuis online ini dapat menjadi solusi jika mahasiswa dengan keterlambatan mengumpulkan kuis pada waktu yang sudah ditentukan maka adanya kuis online ini.

\section{Kesimpulan}

Secara umum dapat disimpulkan bahwa kefektifan e-learning sangat tepat digunakan saat pandemi covid-19. 65\% mahasiswa percaya bahwa mereka setuju dan sepakat untuk menggunakan proses belajar mengajar dengan menggunakan e-learning selama pandemi covid-19. Namun ada beberapa juga kendala pada penelitian ini bagi mahasiswa dan juga dosen. seperti terkendala jaringan atau sinyal pada daerah terpencil bagi mahasiswa dan bagi mahasiswa yang kurang mampu untuk membeli perangkat seperti laptop/komputer yang kurang memadai untuk melakukan pembelajaran $e$ learning. Solusinya bagi pemerintah untuk meluaskan jaringan internet ke daerah terpencil dan bantuan untuk mendapatkan perangkat yang memadai. 


\section{BIBLIOGRAFI}

Abi Yodha, S., Abidin, Z., \& Adi, E. P. (2019). Persepsi mahasiswa terhadap pelaksanaan $e$-learning dalam mata kuliah manajemen sistem informasi mahasiswa Jurusan Teknologi Pendidikan Universitas Negeri Malang. Jurnal Kajian Teknologi Pendidikan, 2 (3), 181-187. Google Scholar

Agus Susilo, F. (2013). Peningkatan Efektivitas Pada Proses Pembelajaran. Mathedunesa, 2 (1). Google Scholar

Anggraini, A. (2018). Keefektifan Pembelajaran Elektronik (E-Learning) Sebagai Pengganti Perkuliahan Konvensional Untuk Meningkatkan Kemampuan Analitis Mahasiswa. Jurnal Penelitian Bidang Pendidikan, 26 (1), 9-23. Google Scholar

Astini, N. K. S. (2020). Pemanfaatan teknologi informasi dalam pembelajaran tingkat sekolah dasar pada masa pandemi covid-19. Lampuh yang, 11(2), 13-25. Google Scholar

Astuti, P., \& Febrian, F. (2019). Blended learning syarah: bagaimana penerapan dan persepsi mahasiswa. Jurnal Gantang, 4 (2), 111-119. Google Scholar

Banamtuan, M. F. (2021). Volume 6 | Nomor 1 | Maret 2021 Analisis Dampak Pembelajaran E-Learning Bagi Kupang Pada Masa Pandemi Covid-19. 6, 13-23. Google Scholar

Daniati, D., Ismanto, B., \& Luhsasi, D. I. (2020). Upaya Peningkatan Motivasi dan Hasil Belajar Mahasiswa dengan Penerapan Model Pembelajaran E-Learning Berbasis Google Classroom pada Masa Pandemi Covid-19. Jurnal Kependidikan: Jurnal Hasil Penelitian Dan Kajian Kepustakaan Di Bidang Pendidikan, Pengajaran Dan Pembelajaran, 6 (3), 601-608. Google Scholar

Engko, C., \& Usmany, P. (2020). Dampak Pandemi Covid-19 Terhadap Proses Pembelajaran Online. Jurnal Akuntansi, 6 (1), 23-38. Google Scholar

Hariani, P. P., \& Wastuti, S. N. Y. (2020). Pemanfaatan e-learning pada pembelajaran jarak jauh di masa pandemi covid-19. Biblio Couns: Jurnal Kajian Konseling Dan Pendidikan, 3(2), 41-49. Google Scholar

Meliyani, M., Supriyanto, S., \& Rahmattullah, M. (2019). Pengaruh Pemanfaatan Simari sebagai Implementasi Pembelajaran Berbasis E-Learning terhadap Hasil Belajar Mahasiswa Prodi Pendidikan Ekonomi. Jurnal Pendidikan Ilmu Sosial, 29 (1), 1-8. Google Scholar

Puspitorini, F. (2020). Strategi Pembelajaran Di Perguruan Tinggi Pada Masa Pandemi Covid-19. Jurnal Kajian Ilmiah, 1 (1), 99-106.

https://doi.org/10.31599/jki.v1i1.274. Google Scholar 
Sara, K., Witi, F. L., \& Mude, A. (2020). Implementasi E-Learning Berbasis Moodle di Masa Pandemi Covid 19. Alignment: Journal of Administration and Educational Management, 3 (2), 181-189. Google Scholar

Wibowo, F. A. N. (2020). Media Pembelajaran E-Learning saat PJJ (Pendidikan Jarak Jauh). Jakarta: Universitas Negeri Jakarta. Google Scholar

Wijaya, R., Lukman, M., \& Yadewani, D. (2020). Dampak Pandemi Covid19 Terhadap Pemanfaatan E-Learning. Jurnal Dimensi, 9 (2), 307-322. Google Scholar

Yuliana, Y. (2020). Analisis Keefektivitasan Pemanfaatan E-Learning Sebagai Media Pembelajaran Pendidikan Agama Islam Pada Masa Pandemi Corona (Covid-19). Salam: Jurnal Sosial Dan Budaya Syar-I, 7 (10), 875-894. https://doi.org/10.15408/sjsbs.v7i10.17371. Google Scholar

\section{Copyright holder:}

Muhammad Zulfan Faizal, Wahyu Andhyka Kusuma (2021)

First publication right:

Jurnal Syntax Admiration

This article is licensed under: 